\title{
The use of medication and associated factors among adults living in Campinas, São Paulo, Brazil: differences between men and women
}

\author{
Uso de medicamentos e fatores associados em adultos residentes \\ em Campinas, São Paulo, Brasil: diferenças entre homens e mulheres
}

Priscila Maria Stolses Bergamo Francisco ${ }^{1}$

Tássia Fraga Bastos ${ }^{1}$

Karen Sarmento Costa ${ }^{1}$

Maria Aparecida Medeiros Barros do Prado ${ }^{1}$

Marilisa Berti de Azevedo Barros ${ }^{1}$

${ }^{1}$ Faculdade de Ciências Médicas, Departamento de Saúde Coletiva,

Universidade Estadual de Campinas. R. Tessália Vieira de Camargo 126, Cidade Universitária. 13083-887 Campinas SP Brasil.

primaria@fcm.unicamp.br
Abstract The objective of this study was to verify factors associated with the use of medication by adults, with emphasis on the differences between men and women. It was a population-based, cross-sectional study with cluster sampling conducted in two stages in Campinas in the state of São Paulo in 2008. Among the 2,413 individuals aged 20 or older, the prevalence of use of at least one drug in the three days before the research was 45.4\% (95\% CI: 41.3 - 49.4) in men and 64.6\% (95\% CI: 59.8 - 69.2) in women. For adult men over 40 years old who were not working, former smokers, with one or more chronic diseases, with two or more health problems and who sought health care or a health professional in the two weeks preceding the research showed higher prevalence of medication use. Among women, a higher prevalence of use was observed in females over 40, obese, former smokers, who reported a short sleep pattern, with one or more chronic diseases and two or more health problems, and who reported seeking a health care service or professional in the past 15 days. The findings showed some differences in the determinants of drug use in relation to gender, revealing the greater importance of health-related behavior among women.

Key words Medication use, Prevalence, Adult population, Epidemiological survey, Pharmacoepidemiology
Resumo O objetivo do presente estudo foi verificar os fatores associados ao uso de medicamentos em adultos, com ênfase nas diferenças entre homens e mulheres. Estudo transversal de base populacional, com amostra por conglomerados $e$ em dois estágios realizado em Campinas em 2008. Entre os 2.413 adultos de 20 anos ou mais, a prevalência de uso de ao menos um medicamento nos três dias que antecederam a pesquisa foi de $45,4 \%$ nos homens e 64,6\% nas mulheres. Entre os homens, indivíduos com idade acima de 40 anos, que não realizavam atividade de trabalho, ex-fumantes, com presença de doenças crônicas e dois ou mais problemas de saúde, e procura por algum serviço de saúde nas duas semanas anteriores à pesquisa apresentaram maiores prevalências de uso de medicamentos. Entre as mulheres, prevalências mais elevadas de uso foram observadas naquelas com idade acima de 40 anos, obesas, ex-fumantes, que referiram padrão de sono curto, com uma ou mais doenças crônicas e dois ou mais problemas de saúde, e que relataram procura de algum serviço de saúde para atendimento nos últimos 15 dias. Os achados apontaram algumas diferenças nos determinantes do uso de medicamentos em relação aos sexos, revelando a maior importância dos comportamentos relacionados à saúde entre as mulheres.

Palavras-chave Uso de medicamentos, Prevalência, População adulta, Inquérito epidemiológico, Farmacoepidemiologia 


\section{Introduction}

The pattern of drug use, including self-medication, has been widely investigated in national and international epidemiological studies, in different population segments ${ }^{1-6}$.

The factors associated with drug use and self-medication, identified in some studies, have revealed differences according to subgroups. Regarding the consumption in adult population, studies have pointed to an increasing use of drugs with increasing age, among women ${ }^{2,7-9}$, those with greater purchasing power ${ }^{7-11}$, among the most educated ${ }^{8,12}$, those that have a higher number of chronic diseases ${ }^{2,7,9,11}$, among others. As for self-medication, a study performed in Bambuí verified that, for the adult population (18 years and older), there is a higher prevalence among men, younger subjects (between 18 and 39 years) and those who reported spending on drugs in the last year. Lower prevalence was observed among those who reported one or more medical appointments 9 .

Drug use has been the subject of constant attention among health care professionals and managers because, while they are necessary for the cure or control of diseases, they may also represent health risks when not rationally used ${ }^{4}$. Among these risks, we highlight the nonuse of the drug in a timely manner, which can lead to delays in diagnosis and therapeutics, adverse interactions with other drugs, bacterial resistance, drug toxicity and poisoning ${ }^{13,14}$.

Considering that there are differences between men and women in relation to the risk of becoming ill, in the perception of signs and symptoms, in seeking health services and in health care, which vary due to the biological, socio-economic and behavioral factors of the gender ${ }^{15,16}$, we must pay attention to the singularities in the profile of drug use in each of these groups.

Comparative studies between men and women point out that, although women report higher prevalence of morbidities ${ }^{17}$, men are more vulnerable to severe chronic diseases, which cause limitations and are important causes of death ${ }^{16,18}$. Besides that, men seek primary care services in a lower proportion than women ${ }^{19}$, most commonly going to emergency rooms, to union clinics and to pharmacies for curative care, resulting in self-medication ${ }^{20}$. Consequently, they are more subject to procedures that could be avoided if preventive measures and the search for health care were carried out early ${ }^{21}$.
Few Brazilian studies have investigated the use of drugs considering the male and female subgroups separately. Thus, the objective of this study was to verify the factors associated with drug use in adults, with an emphasis on the differences between men and women, in the adult population in the city of Campinas, São Paulo, Brazil, in 2008.

\section{Methods}

Population-based, cross-sectional study carried out from 2,476 records of non-institutionalized adults (20 years and older), residents in the urban area in the city of Campinas in the period of 2008 and early 2009. The study used data from the health survey of the city of Campinas (ISACa$\mathrm{mp}$ ), performed by the Collaborating Center on Health Situation Analysis (CCAS) of the Department of Public Health of the School of Medical Sciences, University of Campinas (UNICAMP).

In the survey, the sample was obtained by means of probability sampling, by conglomerates and in two stages, considering the census sectors as primary unit. Thus, in the first stage, 50 census sectors were drawn with probability proportional to size, given by the number of households in the sector. In the second stage, households were selected by systematic randomization applied to the households that had been prepared for each of the selected sectors.

The number of persons to compose the sample was obtained considering the situation corresponding to the maximum variability for the frequency of events studied $(P=0.50), 95 \%$ confidence coefficient in the determination of confidence intervals $(z=1.96)$, sampling error between 4 and 5 percentage points and design effect equal to 2, amounting to 1,000 individuals in each age group, namely: adolescents (10 to 19 years), adults (20 to 59 years) and elderly (60 years and more). Sample size was fixed at 1,250 for $80 \%$ response rate. To achieve this sample size in each domain, after update in the field of the maps of the sectors randomized and preparation of the list of addresses, 2,150, 700 and 3,900 households were selected, independently, for adolescents, adults and the elderly, respectively. In this research, in each household, all residents were interviewed in the age group selected for that address. The sampling design for the ISACamp 2008 survey has been described in detail by Alves $^{22}$. 
The information was obtained through structured questionnaire previously tested in pilot study and applied in household interviews conducted by interviewers trained and supervised. To ensure the quality of the data collected, partial second interviews, performed by telephone or in person, were conducted on random sample of $5 \%$ of the participants and showed no discrepancy in relation to the original information.

In this study, we used the survey's data relating to subjects of 20 years or older and the dependent variable was the use of at least one drug in the three days preceding the survey, investigated by the questions: (1) Have you used any drug in the last three days? (2) How many drugs? Which ones?

For the identification of drugs, we requested the presentation of the drug packaging and/ or the medical prescription to minimize errors in data annotation by the interviewer. Subsequently, the drugs were coded according to the Anatomical Therapeutic Chemical Code (ATC$2009)^{23}$. For the identification of the composition of drugs, we used the "Dicionário de Especialidades Farmacêuticas" (DEF 2008/2009) ${ }^{24}$. For the drugs whose names the interviewee was unable to point out or to provide packing/prescription, we assigned an unidentified code; for products that were not in the ATC, we created codes to identify them, and, for those who did not present a specific code in the ATC, we used the code to the extent that was possible to identify the group, class or therapeutic action.

In the analysis of the factors associated with drug use according to gender, we excluded the records relating to the interviews that related the use of only contraceptives $(n=63)$, as this is a group of drugs unique to women and whose logic differs from the use of other drugs ${ }^{8}$. The following sets of independent variables were selected:

- Demographic and socio-economic: age group, marital status, self-reported color/race, education (in years of study), household income per capita (in minimum wages), job and number of residents in the household.

Health-related behaviors: abusive use of alcohol, assessed by the Alcohol Use Disorder Identification Test (AUDIT) ${ }^{25}$, composed of ten questions and which identifies the risk of alcohol abuse/addiction when its score (0-40 range) equals to eight or more ${ }^{26}$; frequency of alcohol consumption categorized into: no consumption, consumption up to once a week and consumption two or more times a week; smoking categorized into smoker, former smoker and non-smoker; practice of physical activity in the context of leisure (active - individuals who practiced at least 150 minutes per week, distributed, at least, in three days; inadequately active - those who practiced less than 150 minutes or more than 150 minutes, but in less than three days a week, and inactive - those who did not dedicate any time to leisure physical activity during the week); body mass index $\left(\mathrm{BMI}=\mathrm{Kg} / \mathrm{m}^{2}\right)$, calculated based on the weight and height data and cut-off points proposed by the World Health Organization ${ }^{27}$ for the adult population: underweight (BMI $\left.<18.5 \mathrm{~kg} / \mathrm{m}^{2}\right)$, eutrophy $(18.5 \mathrm{~kg} /$ $\left.\mathrm{m}^{2} \leq \mathrm{BMI} \leq 24.9 \mathrm{~kg} / \mathrm{m}^{2}\right) ;$ overweight $\left(25.0 \mathrm{~kg} / \mathrm{m}^{2}\right.$ $\left.\leq \mathrm{BMI}<30.0 \mathrm{~kg} / \mathrm{m}^{2}\right)$ and obese $(\mathrm{BMI} \geq 30 \mathrm{~kg} /$ $\mathrm{m}^{2}$ ); and sleep time (in hours).

- Indicators of health conditions and use of health services: health self-assessment, number of chronic diseases (considering hypertension, diabetes mellitus, cardiovascular disease, tumor/ cancer, rheumatic disease/arthritis/osteoarthritis, osteoporosis, asthma/ bronchitis/emphysema, tendinopathy/Cumulative Trauma Disorders, circulatory problems and others), morbidity in the 15 days prior to the survey, common mental disorder (CMD) evaluated based on the Self Reporting Questionnaire (SQR-20) with cutoff point $7 / 8^{28}$, number of health problems (symptoms/complaints) (frequent headache/migraine disorders, back pain/column problem, hypersensitivity, emotional problem, dizziness/vertigo, insomnia, urinary problem), search for health service or health care professional for health-related issues in the last 15 days, hospitalization in the past year and membership in health plan.

In the data analysis, we initially verified the association between the various variables and drug use according to gender using the Pearson's chi-square testwith a significance level of $5 \%$. Then, considering the effect of age on the greater drug use ${ }^{2,5,7,8,29}$, prevalence ratios (PR) were calculated adjusted for age and 95\% confidence intervals. The multivariate analysis was performed by means of Poisson regression ${ }^{29}$, for both genders, obeying the following hierarchical model: in the first stage, we included the socio-demographic characteristics associated with the use of drugs. In the second stage, in addition to the variables in the first set that maintained significance after being adjusted by the other variables of the same hierarchical level, we added those related to health-related behaviors associated with use, remaining in the model only those that had significance in the adjusting for confounding fac- 
tors belonging to the same hierarchical level and at the higher level. In the third stage, we introduced the variables relating to health conditions, use of health services and subjective health evaluation, given their importance as trigger for the search for medical assistance or other alternatives to improve/recover the health condition ${ }^{7}$. Therefore, we included in the models the variables that showed significant association with drug use in the simple analysis $(\mathrm{p}<0.20)$ and, in the final model, remained those that showed a $\mathrm{p}<0.05$ value, adjusted by the variables of higher levels and at the same level ${ }^{30}$.

Data analyses were performed with the program Stata 11.0, whose procedures for analysis of population surveys incorporate the various aspects of the complex sampling design ${ }^{31}$.

The research project was approved by the Ethics Committee of the University of Campinas.

\section{Results}

Of the adults interviewed by the survey with answers to the question about drug use in the three days preceding the survey, $94.2 \%$ (95\% CI: 90.8 - 97.6) of men and 96.9\% (95\% CI: 95.4 - 98.3) of women responded in person to the interview. The other interviews were answered by a family member or responsible, due to the impossibility arising from the individual's health problems. The average age of the study population was 41.6 years (95\% CI: 40.3 - 42.9) and 43.7 (95\% CI: 42.4 - 45.0) for men and women, respectively. Regarding drug use, $45.4 \%$ (95\% CI: 41.3 - 49.4) of men and $68.0 \%$ (95\% CI: 63.5 - 72.5) of women reported having consumed at least one drug in the three days preceding the survey.

Excluding the specific usage of contraceptives, according to the criteria adopted, the prevalence of use among women $(\mathrm{n}=1,350)$ was 64.6\% (95\% CI: 59.8 - 69.2) and the average number of drugs used by the adult population investigated in this study $(\mathrm{n}=2,413)$ was 1.5 (95\% CI: 1.3 - 1.6) for women and 0.9 (95\% CI: 0.8 - 1.0) for men.

Table 1 presents the prevalence of drug use, by gender, according to socio-demographic variables. We observed that, in the simple analysis, age group, education and job were associated with drug use for both genders $(\mathrm{p}<0.05)$. Marital status was associated only with men and, in relation to household income per capita and number of people in the household, there was an association only for women $(\mathrm{p}<0.05)$. After adjusting for age, higher prevalence of drug use was verified in women who did not have any jobs at the time of the survey, in the limit of statistical significance (PR $=1.13$; 95\% CI: 1.00 - 1.29). Women showed a higher prevalence of drug use than men, except for the age group of 80 years or more and among the persons with less education.

With regard to health-related behaviors in the male adult population, we observed significantly higher prevalences of drug use among those who stopped smoking and those overweight. Regarding the women, greater use was verified among those who no longer smoke, the obese and those who reported a short sleep pattern (up to 6 hours). Underweight women showed lower prevalence of drug use after adjusting for age (PR $=0.66$; 95\% CI: 0.46-0.95) (Table 2). In assessing the prevalence ratio between the genders, we observed that the prevalence of drug use for women were not higher than those for men only for those who abused alcohol, those insufficiently active and in those underweight.

Table 3 presents the prevalence of drug use according to health condition and use of health services. All variables concerning health conditions were significantly associated with drug use in the analysis stratified by gender, as well as the search for health service or health care professional in the past 15 days. Among men, hospitalization in the previous year was also associated with drug use. The magnitudes of associations evaluated by means of prevalence ratios adjusted for age, in general, show the greater magnitude of associations among men. For the set of variables analyzed, women showed higher prevalence of drug use, compared to men, for at least one of the categories considered (Table 3 ).

The hierarchical multiple regression analysis results are presented in Tables 4 and 5. For the male adult population, among the socio-demographic variables, age group above 40 years and no job remained statistically associated with drug use. Of the variables from the set concerning health-related behaviors, only former smokers had higher prevalence of drug use, after adjustment by the variables of the same set, and by those that remained from the set of socio-demographic characteristics. In the set integrated by health conditions, use of health services and subjective health evaluation, the following variables remained positively associated: presence of one or more chronic disease, presence of two or more health problems (symptoms/complaints) and search for health service or health care professional in the past 15 days, when adjusted among 
Table 1. Prevalence of drug use, by gender, according to demographic and socio-economic variables in the adult population (20 years or older) of Campinas in 2008. Campinas Health Survey, 2008.

\begin{tabular}{|c|c|c|c|c|c|c|c|}
\hline \multirow[b]{2}{*}{ Variables } & \multicolumn{3}{|c|}{ Men } & \multicolumn{3}{|c|}{ Women } & \multirow[b]{2}{*}{$\begin{array}{r}\text { Adjusted } \mathrm{PR}^{* *} \\
(2) /(1)\end{array}$} \\
\hline & $\begin{array}{c}n= \\
1.063\end{array}$ & $\begin{array}{l}\text { Prevalence } \\
\qquad \%)(1)\end{array}$ & $\begin{array}{l}\text { Adjusted PR } \\
(95 \% \mathrm{CI})^{* *}\end{array}$ & $\begin{array}{r}n= \\
1.350\end{array}$ & $\begin{array}{l}\text { Prevalence } \\
\quad(\%)(2)\end{array}$ & $\begin{array}{l}\text { Adjusted PR } \\
(95 \% \mathrm{CI})^{* *}\end{array}$ & \\
\hline \multicolumn{8}{|l|}{$\begin{array}{l}\text { Socio-economic and } \\
\text { demographic }\end{array}$} \\
\hline Age group & & $\mathrm{p}=0.0000^{*}$ & & & $\mathrm{p}=0.0000^{*}$ & & \\
\hline 20 to 39 & 256 & 31.8 & 1 & 222 & 51.8 & 1 & $1.63(1.31-2.01)$ \\
\hline 40 to 59 & 193 & 53.6 & $1.68(1.29-2.19)$ & 227 & 67.1 & $1.29(1.13-1.48)$ & $1.25(1.07-1.46)$ \\
\hline 60 to 79 & 549 & 70.7 & $2.22(1.83-2.69)$ & 769 & 86.2 & $1.66(1.49-1.86)$ & $1.22(1.14-1.30)$ \\
\hline 80 or more & 65 & 84.7 & $2.66(2.13-2.33)$ & 132 & 88.6 & $1.71(1.50-1.96)$ & $1.05(0.93-1.17)$ \\
\hline Marital Status & & $\mathrm{p}=0.0035^{*}$ & & & $\mathrm{p}=0.8102^{*}$ & & \\
\hline With partner & 754 & 50.5 & $1.11(0.89-1.38)$ & 647 & 64.3 & $1.04(0.93-1.16)$ & $1.31(1.16-1.48)$ \\
\hline Without partner & 309 & 36.4 & 1 & 703 & 65.1 & 1 & $1.45(1.16-1.81)$ \\
\hline Race/color & & $\mathrm{p}=0.4983^{*}$ & & & $\mathrm{p}=0.2103^{*}$ & & \\
\hline White & 776 & 46.4 & $1.01(0.81-1.27)$ & 1029 & 66.2 & $1.04(0.90-1.21)$ & $1.34(1.20-1.50)$ \\
\hline Non-white & 284 & 42.8 & 1 & 320 & 60.4 & 1 & $1.33(1.07-1.65)$ \\
\hline Education & & $\mathrm{p}=0.0004^{*}$ & & & $\mathrm{p}=0.0008^{*}$ & & \\
\hline 0 to 3 years & 203 & 74.0 & $1.15(0.93-1.42)$ & 401 & 76.9 & $1.01(0.85-1.21)$ & $1.03(0.86-1.23)$ \\
\hline 4 to 8 years & 391 & 45.8 & $0.95(0.77-1.17)$ & 529 & 68.6 & $1.06(0.92-1.21)$ & $1.43(1.26-1.62)$ \\
\hline 9 or more years & 469 & 41.4 & 1 & 419 & 58.1 & 1 & $1.37(1.15-1.63)$ \\
\hline $\begin{array}{l}\text { Household income } \\
\text { per capita (MW) }\end{array}$ & & $\mathrm{p}=0.4087^{*}$ & & & $\mathrm{p}=0.0399^{*}$ & & \\
\hline up to 1 & 410 & 43.3 & 1 & 586 & 61.1 & 1 & $1.33(1.16-1.53)$ \\
\hline$>1$ to $<3$ & 429 & 44.9 & $1.04(0.87-1.24)$ & 529 & 70.5 & $1.11(0.99-1.25)$ & $1.43(1.24-1.65)$ \\
\hline$\geq 3$ & 224 & 50.5 & $1.10(0.89-1.35)$ & 235 & 62.3 & $1.03(0.90-1.18)$ & $1.24(1.00-1.54)$ \\
\hline Job & & $\mathrm{p}=0.0000^{*}$ & & & $\mathrm{p}=0.0000^{*}$ & & \\
\hline Yes & 582 & 40.5 & 1 & 385 & 56.2 & 1 & $1.37(1.16-1.61)$ \\
\hline No & 480 & 62.8 & $1.14(0.92-1.42)$ & 965 & 73.4 & $1.13(1.00-1.29)$ & $1.19(1.04-1.36)$ \\
\hline $\begin{array}{l}\text { \# persons in the } \\
\text { household }\end{array}$ & & $\mathrm{p}=0.1654^{*}$ & & & $\mathrm{p}=0.0224^{*}$ & & \\
\hline 1 to 2 persons & 431 & 51.6 & $0.98(0.81-1.18)$ & 596 & 73.2 & $1.01(0.86-1.19)$ & $1.32(1.11-1.57)$ \\
\hline 3 to 4 persons & 430 & 43.7 & $0.96(0.77-1.20)$ & 493 & 60.7 & $0.94(0.81-1.09)$ & $1.32(1.12-1.55)$ \\
\hline 5 or more & 202 & 42.0 & 1 & 261 & 62.2 & 1 & $1.39(1.17-166)$ \\
\hline
\end{tabular}

n: number of individuals in the unweighted sample. ${ }^{*}$ p-value of the chi-square test. ${ }^{* *}$ Prevalence ratio adjusted by age.

each other and for the variables that persisted in the previous sets (Table 4).

In relation to the female population, among the socio-demographic variables, only the age group older than 40 years remained statistically associated with drug use, after adjustment by the variables of the same set. For the health-related behaviors, former smokers, obese and those who reported a short sleeping pattern presented higher prevalence, and underweight women showed a lower prevalence of drug use, after adjustment by the variables of the same set and by the age groups. In the set related to health conditions, use of health services and subjective health evaluation, the following variables remained positively associated: presence of one or more chronic dis- ease, presence of two or more health problems (symptoms/complaints) and search for health service or health care professional in the past 15 days, when adjusted among each other and for the variables that were kept in the previous sets (Table 5).

\section{Discussion}

The prevalence of use of at least one drug in the three days preceding the survey was of $45.4 \%$ and $64.6 \%$ among adult men and women residing in Campinas, respectively. In the research on drug use, we should consider the recall period, as the prevalence of use depends on the period evaluat- 
Table 2. Prevalence of drug use, by gender, according to behavioral variables related to health and use of health services in the adult population (20 years or older) of Campinas in 2008. Campinas Health Survey, 2008.

\begin{tabular}{|c|c|c|c|c|c|c|c|}
\hline \multirow[b]{2}{*}{ Variables } & \multicolumn{3}{|c|}{ Men } & \multicolumn{3}{|c|}{ Women } & \multirow[b]{2}{*}{$\begin{array}{r}\text { Adjusted } \mathrm{PR}^{*} \\
(2) /(1)\end{array}$} \\
\hline & $\begin{array}{c}n= \\
1.063\end{array}$ & $\begin{array}{l}\text { Prevalence } \\
\text { (\%) (1) }\end{array}$ & $\begin{array}{l}\text { Adjusted PR } \\
(95 \% \mathrm{CI})^{* *}\end{array}$ & $\begin{array}{r}n= \\
1.350\end{array}$ & $\begin{array}{l}\text { Prevalence } \\
\quad(\%)(2)\end{array}$ & $\begin{array}{l}\text { Adjusted PR } \\
(95 \% \mathrm{CI})^{* *}\end{array}$ & \\
\hline \multicolumn{8}{|l|}{ Health-related behaviors } \\
\hline Abusive use of alcohol / & & $\mathrm{p}=0.8406^{*}$ & & & & & \\
\hline alcohol addiction & & & & & $\mathrm{p}=0.2824^{*}$ & & \\
\hline Yes & 128 & 44.3 & 1 & 18 & 53.5 & 1 & $1.35(0.89-2.05)$ \\
\hline No & 933 & 45.6 & $1.00(0.76-1.32)$ & 1329 & 64.9 & $1.08(0.74-1.57)$ & $1.34(1.20-1.49)$ \\
\hline $\begin{array}{l}\text { Frequency of consumption } \\
\text { of alcoholic drinks/week }\end{array}$ & & $\mathrm{p}=0.0472^{*}$ & & & $\mathrm{p}=0.3130^{*}$ & & \\
\hline No consumption & 515 & 52.3 & 1 & 1022 & 66.2 & 1 & $1.21(1.04-1.41)$ \\
\hline Up to once & 323 & 39.5 & $0.85(0.70-1.05)$ & 283 & 59.4 & $0.94(0.79-1.12)$ & $1.38(1.13-1.68)$ \\
\hline Two or more times & 223 & 42.3 & $0.80(0.60-1.06)$ & 42 & 70.4 & $1.11(0.86-1.42)$ & $1.70(1.34-2.16)$ \\
\hline Smoking & & $\mathrm{p}=0.0001^{*}$ & & & $\mathrm{p}=0.0051^{*}$ & & \\
\hline Smoker & 203 & 38.2 & $0.88(0.69-1.15)$ & 157 & 61.5 & $1.00(0.85-1.17)$ & $1.50(1.16-1.95)$ \\
\hline Former smoker & 257 & 68.7 & $1.27(1.05-1.54)$ & 154 & 83.1 & $1.29(1.12-1.49)$ & $1.26(1.04-1.52)$ \\
\hline Never smoked & 602 & 42.7 & 1 & 1037 & 62.5 & 1 & $1.34(1.18-1.51)$ \\
\hline $\begin{array}{l}\text { Physical activity during } \\
\text { leisure }\end{array}$ & & $\mathrm{p}=0.0920^{*}$ & & & $\mathrm{p}=0.1399^{*}$ & & \\
\hline Active & 245 & 40.5 & 1 & 246 & 71.7 & 1 & $1.57(1.27-1.94)$ \\
\hline Inadeq. Active & 153 & 40.3 & $1.11(0.83-1.50)$ & 139 & 57.8 & $0.81(0.64-1.02)$ & $1.08(0.80-1.44)$ \\
\hline No physical activity & 665 & 49.0 & $1.14(0.90-1.43)$ & 965 & 63.8 & $0.92(0.79-1.06)$ & $1.28(1.13-1.46)$ \\
\hline $\mathrm{BMI}\left(\mathrm{Kg} / \mathrm{m}^{2}\right)$ & & $\mathrm{p}=0.0413^{*}$ & & & $\mathrm{p}=0.0000^{*}$ & & \\
\hline Underweight $(<18.5)$ & 25 & 45.5 & $1.12(0.64-1.95)$ & 59 & 37.7 & $0.66(0.46-0.95)$ & $0.84(0.44-1.60)$ \\
\hline Eutrophic (18.5 to 24.9 ) & 486 & 39.6 & 1 & 533 & 58.5 & 1 & $1.41(1.19-1.67)$ \\
\hline Overweight (25 to 29.9 ) & 397 & 50.8 & $1.21(1.02-1.45)$ & 448 & 69.8 & $1.12(0.98-1.28)$ & $1.28(1.08-1.52)$ \\
\hline Obese $(\geq 30)$ & 155 & 51.3 & $1.18(0.94-1.48)$ & 310 & 77.1 & $1.23(1.09-1.38)$ & $1.41(1.19-1.67)$ \\
\hline Hours of sleep & & $\mathrm{p}=0.8920^{*}$ & & & $\mathrm{p}=0.0021^{*}$ & & \\
\hline Up to 6 & 174 & 46.5 & $0.96(0.77-1.20)$ & 261 & 78.9 & $1.22(1.09-1.37)$ & $1.60(1.22-2.08)$ \\
\hline 7 to 8 & 630 & 44.8 & 1 & 782 & 60.7 & 1 & $1.26(1.11-1.43)$ \\
\hline 9 or more & 257 & 46.7 & $0.98(0.80-1.20)$ & 292 & 65.4 & $1.08(0.92-1.28)$ & $1.37(1.12-1.69)$ \\
\hline
\end{tabular}

n: number of individuals in the unweighted sample. ${ }^{*}$ p-value of the chi-square test. ${ }^{* *}$ Prevalence ratio adjusted by age.

ed. The literature does not point an ideal period, as this choice depends on what is being recorded and the ability of the respondent population to recall ${ }^{10}$; however, regardless of this period, the accuracy of the respondent for drug use decreases with increasing age, number of drugs prescribed for chronic use and also can vary depending on the drug used ${ }^{32}$.

The increased use of drugs by women compared to men is consistent with the results obtained in many other epidemiological investigations ${ }^{2,5-8,12,15,33}$ and is independent of type of use (prescribed or over-the-counter) ${ }^{7}$. In one of the first Brazilian research studies to analyze the profile of population-based drug consumption, held in the city of Ribeirão Preto (SP) in the 70s, there was already a greater drug usage by women with higher rates of morbidity, drug consumption and medical appointments, which sharply contrasted with the greater male mortality ${ }^{34}$. There are several aspects that make women more prone to drug use, among them stand out their greater concern with health, their performance in the health care of their family members, early and more frequent search for health services, probably due to greater opportunity for care (the incorporation of attention to women's health into national health policies date from the early 20th century) ${ }^{35}$.

In addition, the existing specific programs $s^{35}$ are disseminated and directed to the problems that affect women in every stage of life (such as in the menstrual period, symptoms and effects of estrogen deficiency) and contribute to a greater chance of drug use during adulthood, factors 
Table 3. Prevalence of drug use, by gender, according to the variables of health conditions and use of health services in the adult population (20 years or older) of Campinas in 2008. Campinas Health Survey, 2008.

\begin{tabular}{|c|c|c|c|c|c|c|c|}
\hline \multirow[b]{2}{*}{ Variables } & \multicolumn{3}{|c|}{ Men } & \multicolumn{3}{|c|}{ Women } & \multirow[b]{2}{*}{$\begin{array}{r}\text { Adjusted PR } \\
\qquad(2) /(1)\end{array}$} \\
\hline & $\begin{array}{c}n= \\
1.063\end{array}$ & $\begin{array}{l}\text { Prevalence } \\
\quad(\%)(1)\end{array}$ & $\begin{array}{c}\text { Adjusted PR } \\
(95 \% \mathrm{CI})\end{array}$ & $\begin{array}{r}n= \\
1.350\end{array}$ & $\begin{array}{l}\text { Prevalence } \\
\quad(\%)(2)\end{array}$ & $\begin{array}{l}\text { Adjusted PR } \\
\qquad(95 \% \mathrm{CI})^{*}\end{array}$ & \\
\hline \multicolumn{8}{|l|}{ Health conditions } \\
\hline Health self-assessment & & $\mathrm{p}=0.0000^{*}$ & & & & & \\
\hline Excellent/Very good & 362 & 36.3 & 1 & 371 & $\mathrm{p}=0.0000^{*}$ & & \\
\hline Good & 601 & 48.4 & $1.19(0.98-1.45)$ & 829 & 52.8 & 1 & $1.38(1.12-1.70)$ \\
\hline Bad/Very bad & 100 & 83.1 & $1.84(1.47-2.30)$ & 150 & 67.5 & $1.20(1.00-1.44)$ & $1.32(1.14-1.52)$ \\
\hline \# of chronic diseases & & $\mathrm{p}=0.0000^{*}$ & & & 93.6 & $1.59(1.33-1.90)$ & $1.12(0.92-1.36)$ \\
\hline 0 & 469 & 28.2 & 1 & 369 & $\mathrm{p}=0.0000^{*}$ & & \\
\hline 1 & 269 & 65.9 & $2.12(1.73-2.61)$ & 300 & 42.7 & 1 & $1.51(1.20-1.90)$ \\
\hline 2 & 168 & 87.0 & $2.53(2.04-3.14)$ & 254 & 70.8 & $1.62(1.35-1.94)$ & $1.07(0.93-1.23)$ \\
\hline 3 & 92 & 80.2 & $2.13(1.63-2.79)$ & 193 & 93.2 & $2.07(1.73-2.48)$ & $1.07(0.97-1.18)$ \\
\hline 4 or more & 56 & 96.7 & $2.47(2.02-3.02)$ & 211 & 95.2 & $2.10(1.72-2.55)$ & $1.23(0.97-1.55)$ \\
\hline \# of health problems & & $\mathrm{p}=0.0000^{*}$ & & & 99.1 & $2.15(1.80-2.56)$ & $1.02(0.97-1.08)$ \\
\hline 0 & 409 & 34.4 & 1 & 307 & $\mathrm{p}=0.0000^{*}$ & & \\
\hline 1 & 327 & 46.8 & $1.29(1.07-1.55)$ & 364 & 43.0 & 1 & $1.21(0.91-1.62)$ \\
\hline 2 & 190 & 52.2 & $1.46(1.16-1.84)$ & 282 & 57.9 & $1.28(0.96-1.70)$ & $1.15(0.94-1.41)$ \\
\hline 3 & 94 & 68.7 & $1.78(1.34-2.37)$ & 199 & 72.0 & $1.59(1.19-2.13)$ & $1.30(1.04-1.61)$ \\
\hline 4 or more & 43 & 85.8 & $2.11(1.63-2.73)$ & 198 & 81.4 & $1.77(1.33-2.37)$ & $1.18(0.90-1.54)$ \\
\hline Common Mental Disorder & & $\mathrm{p}=0.0030^{*}$ & & & 89.8 & $1.91(1.50-2.43)$ & $1.04(0.85-1.27)$ \\
\hline Yes & 85 & 76.2 & $1.55(1.19-2.01)$ & 235 & $\mathrm{p}=0.0000^{*}$ & & \\
\hline No & 977 & 43.5 & 1 & 1114 & 89.2 & $1.36(1.24-1.49)$ & $1.15(0.92-1.42)$ \\
\hline Use of health services & & & & & 60.5 & 1 & $1.32(1.18-1.47)$ \\
\hline $\begin{array}{l}\text { Search for health service } \\
\text { or health care professional } \\
\text { in the past } 15 \text { days }\end{array}$ & & $\mathrm{p}=0.0000^{*}$ & & & $\mathrm{p}=0.0001^{*}$ & & \\
\hline Yes & 198 & 75.8 & $1.72(1.45-2.04)$ & 348 & 81.7 & $1.34(1.18-1.52)$ & $1.07(0.90-1.26)$ \\
\hline No & 865 & 40.0 & 1 & 1002 & 59.3 & 1 & $1.37(1.21-1.57)$ \\
\hline Hospitalization in the & & & & & $\mathrm{p}=0.1815^{*}$ & & \\
\hline previous year & & $\mathrm{p}=0.0223^{*}$ & $1.12(0.92-1.38)$ & 172 & 71.7 & $1.09(0.94-1.28)$ & $1.24(0.97-1.58)$ \\
\hline Yes & 124 & 59.7 & 1 & 1178 & 63.7 & 1 & $1.34(1.20-1.51)$ \\
\hline No & 939 & 44.2 & & & $\mathrm{p}=0.1145^{*}$ & & \\
\hline Health plan & & $\mathrm{p}=0.4897^{*}$ & & & & & \\
\hline Yes & 458 & 47.2 & $1.05(0.86-1.27)$ & 638 & 68.4 & $1.09(0.95-1.24)$ & $1.36(1.16-1.60)$ \\
\hline No & 605 & 44.1 & 1 & 710 & 61.4 & 1 & $1.32(1.15-1.51)$ \\
\hline
\end{tabular}

n: number of individuals in the unweighted sample. ${ }^{*}$-value of the chi-square test. ${ }^{\text {** }}$ Prevalence ratio adjusted by age.

that may partially explain the greater use in this group. In the study conducted by Pedro et al..$^{36}$ in Campinas about the search for medical services among menopausal women revealed that, for the major complaints (menstrual irregularity, climacteric symptoms and urogenital symptoms), all women were medicated and almost all followed the prescription indicated.

Pelicioni and César ${ }^{33}$, based on data from a home health survey carried out in four areas of the State of São Paulo (ISA-SP), observed increased drug use in the higher age groups and a higher prevalence among women compared to men, considering the same period used in the present study, which was also verified by Costa et al. ${ }^{2}$ with health survey data in the State of São Paulo (ISA-SP) and by Perrone et al. ${ }^{37}$ on the analysis of ISA-SP data disaggregated for the city of Campinas. This trend, also observed in the present study, is consistent in the literature and, possibly, is due to the higher prevalence of co-morbidities with advancing age ${ }^{38}$. In this study, we could observe that the increasing drug use according to age groups occurs differently in 
Table 4. Final results of the hierarchical regression analysis of factors associated with drug use in the male adult population (20 years or older). Campinas, São Paulo. Campinas Health Survey, 2008.

\begin{tabular}{|c|c|c|c|}
\hline Variable & $\begin{array}{c}\text { First step } \\
\text { Adjusted } \text { PR }^{*}(95 \% \mathrm{CI})\end{array}$ & $\begin{array}{c}\text { Second step } \\
\text { Adjusted } \mathbf{P R}^{* *}(\mathbf{9 5 \%} \mathrm{CI})\end{array}$ & $\begin{array}{c}\text { Third step } \\
\text { Adjusted } \mathrm{PR}^{* * *}(95 \% \mathrm{CI})\end{array}$ \\
\hline \multicolumn{4}{|l|}{ Age groups (years) } \\
\hline 20 to 39 & 1 & & \\
\hline 40 to 59 & $1.68(1.29-2.18)$ & & \\
\hline 60 to 79 & $1.95(1.57-2.44)$ & - & - \\
\hline 80 or more & $2.18(1.67-2.85)$ & & \\
\hline \multicolumn{4}{|l|}{ Job } \\
\hline Yes & 1 & & \\
\hline No & $1.28(1.05-1.57)$ & - & - \\
\hline \multicolumn{4}{|l|}{ Smoking } \\
\hline Never smoked & & 1 & \\
\hline Smoker & & $0.85(0.66-1.09)$ & - \\
\hline Former smoker & & $1.31(1.09-1.58)$ & \\
\hline \multicolumn{4}{|l|}{ \# of chronic diseases } \\
\hline 0 & & & 1 \\
\hline 1 & & & $1.98(1.63-2.40)$ \\
\hline 2 & & & $2.34(1.93-2.84)$ \\
\hline 3 & & & $1.99(1.45-2.73)$ \\
\hline 4 or more & & & $2.10(1.68-2.63)$ \\
\hline \multicolumn{4}{|l|}{ \# of health problems } \\
\hline 0 & & & 1 \\
\hline 1 & & & $1.25(1.01-1.55)$ \\
\hline 2 & & & $1.40(1.13-1.73)$ \\
\hline 3 & & & $1.35(1.03-1.75)$ \\
\hline 4 or more & & & $1.57(1.26-1.93)$ \\
\hline \multicolumn{4}{|c|}{$\begin{array}{l}\text { Search for health service or } \\
\text { health professional in the } \\
\text { past } 15 \text { days }\end{array}$} \\
\hline No & & & 1 \\
\hline Yes & & & $1.51(1.26-1.81)$ \\
\hline
\end{tabular}

"Adjusted by the socio-demographic variables. ${ }^{* *}$ Adjusted by the socio-demographic and health-related behavior variables. ${ }^{* * *}$ Adjusted by the socio-demographic, health-related behavior, health condition, use of services, and health self-assessment variables. PR: Prevalence ratio adjusted by means of Poisson multiple regression.

relation to gender and that only for the elderly there were no differences in the prevalence ratio according to gender.

The average number of drugs consumed by the adult population of Campinas was similar to that observed for studies performed with the same period recorded ${ }^{2,37}$.

Marital status and education among men, as well as education, household income per capita, job and number of people in the household among women, who had association with drug use in the simple analysis, lost their significance after the adjusted analysis, as verified in other studies ${ }^{6,8}$. Studies indicate the importance of the socio-economic level and, specifically, the monthly family income as determinants of drug consumption $^{5-8}$, which was not verified in this study for the variables analyzed.

Among men, there was a higher prevalence of drug use in those who did not have a job at the time of the research. In a study performed in Catalonia with adult population of 25 to 64 years, there was higher drug consumption among retired men, but not among the women ${ }^{6}$. Moreover, in relation to job, some studies have found higher prevalence of drug use and self-medication among the unemployed, students and housewives ${ }^{7,39,40}$. In this study, drug use was not evaluated according to prescription, but when comparing genders, drug consumption without medical or dental indication showed no statistical difference (data not presented). 
Table 5. Final results of the hierarchical regression analysis of factors associated with drug use in the female adult population (20 years or older). Campinas, São Paulo. Campinas Health Survey, 2008.

\begin{tabular}{|c|c|c|c|}
\hline Variable & $\begin{array}{c}\text { First step } \\
\text { Adjusted } \mathrm{PR}^{*}(95 \% \mathrm{CI})\end{array}$ & $\begin{array}{c}\text { Second step } \\
\text { Adjusted } \mathrm{PR}^{* *}(95 \% \mathrm{CI})\end{array}$ & $\begin{array}{c}\text { Third step } \\
\text { Adjusted } \mathrm{PR}^{* * *}(95 \% \mathrm{CI})\end{array}$ \\
\hline \multicolumn{4}{|l|}{ Age groups (years) } \\
\hline 20 to 39 & 1 & & \\
\hline 40 to 59 & $1.29(1.12-1.48)$ & & \\
\hline 60 to 79 & $1.65(1.48-1.84)$ & - & - \\
\hline 80 or more & $1.69(1.47-1.94)$ & & \\
\hline \multicolumn{4}{|l|}{ Smoking } \\
\hline Never smoked & & 1 & \\
\hline Smoker & & $1.00(0.86-1.18)$ & - \\
\hline Former smoker & & $1.26(1.10-1.45)$ & \\
\hline \multicolumn{4}{|l|}{$\operatorname{BMI}\left(\mathrm{Kg} / \mathrm{m}^{2}\right)$} \\
\hline Underweight $(<18.5)$ & & $0.63(0.43-0.92)$ & \\
\hline Eutrophic (18.5 to 24.9 ) & & 1 & \\
\hline Overweight (25 to 29.9 ) & & $1.11(0.96-1.27)$ & \\
\hline Obese $(\geq 30)$ & & $1.20(1.05-1.37)$ & - \\
\hline \multicolumn{4}{|l|}{ Hours of sleep } \\
\hline Up to 6 & & $1.19(1.06-1.35)$ & \\
\hline 7 to 8 & & 1 & - \\
\hline 9 or more & & $1.08(0.92-1.26)$ & \\
\hline \multicolumn{4}{|l|}{ \# of chronic diseases } \\
\hline 0 & & & 1 \\
\hline 1 & & & $1.48(1.24-1.78)$ \\
\hline 2 & & & $1.68(1.39-2.05)$ \\
\hline 3 & & & $1.70(1.39-2.09)$ \\
\hline 4 or more & & & $1.67(1.39-2.02)$ \\
\hline \multicolumn{4}{|l|}{ \# of health problems } \\
\hline 0 & & & 1 \\
\hline 1 & & & $1.23(0.87-1.72)$ \\
\hline 2 & & & $1.55(1.14-2.12)$ \\
\hline 3 & & & $1.53(1.08-2.17)$ \\
\hline 4 or more & & & $1.65(1.21-2.25)$ \\
\hline \multicolumn{4}{|l|}{$\begin{array}{l}\text { Search for health service or } \\
\text { health professional in the } \\
\text { past } 15 \text { days }\end{array}$} \\
\hline No & & & 1 \\
\hline Yes & & & $1.15(1.02-1.31)$ \\
\hline
\end{tabular}

"Adjusted by the socio-demographic variables. ${ }^{* *}$ Adjusted by the socio-demographic and health-related behavior variables. *** Adjusted by the socio-demographic, health-related behavior, health condition, use of services, and health self-assessment variables. PR: Prevalence ratio adjusted by means of Poisson multiple regression.

With regard to health-related behaviors, we observed higher prevalence of drug use among men and women who stopped smoking. The same trend was observed for point estimates in the study of Bardel, et al..$^{38}$, without, however, achieving statistical significance. The higher prevalence of use could be partially explained as these persons constitute a group with worse health conditions, resulting from the effect of smoke exposure, which may have even motivated the abandonment of smoking 8 . Evidence shows smoking as part of the chain of causality of almost 50 different diseases, including cardiovascular diseases, cancers and respiratory diseases ${ }^{41}$.

Also among women, underweight was inversely associated with use, and obesity and short sleep pattern had higher prevalence of drug use. Bardel, et al. ${ }^{38}$, in a study with Swedish women of 35 to 65 years in Sweden, and Bertoldi, et al. ${ }^{8}$ verified that prevalences of drug use were sig- 
nificantly higher among the obese, as verified in the present study; however, in both studies, the category underweight $(\mathrm{BMI}<18.5)$ was not considered. The association between obesity and chronic morbidities, such as diabetes mellitus, hypertension and cardiovascular diseases (data not shown), consistent with health surveys conducted elsewhere ${ }^{42,43}$, may partially explain this finding. In this study, among women who had the desire to lose weight, the use of medications for weight loss was rarely mentioned.

In this study, sleep duration equal to less than 6 hours was positively associated with drug use among women. Epidemiological studies have observed that the pattern of short or long sleep is associated with increased morbidity ${ }^{44-46}$. Changes in sleep duration can be peculiar symptoms of diseases, but the use of medicines can also change the sleep pattern. In this sense, it is not possible to clarify the cause-and-effect relationship of this association in a cross-sectional study, due to the possibility of reverse causality, which highlights the need for studies to find, from the pharmacological point of view, what is the relationship between the specific drugs used and their association with the sleep pattern in more detail.

In relation to health conditions and the use of health services, for the presence of chronic disease, which is the main determinant of drug use in both genders ${ }^{2,7,9,11}$, the magnitudes of associations were higher among men.

In this study, health problems (symptoms/ complaints) often referred to by the adult population were considered in the analysis with the objective of scaling their importance and magnitude given the indicators traditionally used in studies on drug use, and, for both men and women, they were significantly associated with drug use. The health problems mentioned by the population determine the drug use for a real need and the symbolic function of the drugs. Also, in addition to cultural and behavioral factors that partially explain the use, the need motivated by advertisements promoted by the pharmaceutical industry and primarily related to non-prescription drugs heavily contribute to the use ${ }^{47}$. We stress that when handling these problems/ complaints - which may harbor other more serious health problems that require specific care and/or treatment - non-prescription drugs are often used (self-medication) and the drugs commonly used in these cases belong to the group of analgesics, antipyretics and NSAIDs (data not presented). Information based on scientific evidence and knowledge in pharmacology enables the pharmacist to take actions that can improve the practice of self-medication subsidizing the proper use of these drugs ${ }^{39,48}$. In this sense, the pharmacist has the important role of providing sufficient information to ensure the responsible self-medication.

The search for health services or a health care professional in the 15 days before the survey was significantly associated with drug use. Studies indicate a high proportion of drug prescription for respondents who seek health care ${ }^{5,7,15,49}$. The medicalization of society is a complex phenomenon related to socio-cultural, political and scientific transformations based on the incorporation of standards of conduct of biomedical origin, on the general culture, and on the redefinition of human experiences associated with medical problems ${ }^{47}$. Excess drug use cannot be attributed solely to medical action, but to the reduction of sickness caused by a problem in the "human machine", disregarding the social, behavioral, cultural and psychological determinants related to the health-disease process ${ }^{47,50}$. However, the medical care, commonly classified by the user as quick, superficial and impersonal, often has been summarized to the prescription of the best drug suited to the symptoms ${ }^{7,39}$.

Among the limitations of this study, the three-day recall period may underestimate the prevalence of use, since, the longer is the period (15 or 30 days), the greater will be the likelihood of an eventual use of a drug. The continuous-use medication can also be counted in any length of period. However, we must consider that a longer period could also generate a memory bias in relation to drugs of sporadic use, commonly used by the adult population and without medical prescription, promoting an understating especially about the pharmaceuticals used for minor illnesses $^{1,2,8}$. We should also consider that this study used data from a comprehensive health survey, which may lead to different results than the ones obtained from a specific survey on this theme.

Even though the period remembered when obtaining information is an important methodological aspect in comparative approaches, we observed a high prevalence of drug use in the adult population of Campinas, which is also influenced by the availability and quality of medical care services, among other factors not assessed in this study.

The differences observed in the prevalence and magnitude of drug use reflect the specificities of the subgroups evaluated with regard to socio-demographic characteristics, health-relat- 
ed behaviors, health status and service use. In this study, the findings showed some differences in determinants of drug use in relation to gender, revealing the greater importance of obesity and the short sleep pattern among women. They also revealed that, despite the higher prevalence of drug use among women for almost all variables considered, the growing trend of drug use according to age groups and an increase in the number of chronic diseases was more markedly noted among men. This allowed us to identify the importance of health problems/complaints often referred to by the population, regarding the use of drugs and health-related behavior, especially among adult women in Campinas.

Studies that include the identification of drugs that are being used by specific population groups may contribute to the knowledge about the profile of medical prescription and self-medication, as well as a more detailed investigation with regard to the appropriateness of use, given the morbidities.

\section{Collaborations}

PMSB Francisco carried out the proposed article, literature review, data analysis and writing of the text. TF Bastos collaborated on the literature review, data analysis and writing of the text. KS Costa and MAMB Prado contributed to the literature review of the manuscript. MBA. Barros guided the proposed article, conducted the review of the manuscript and coordinated the Health Survey in Campinas (ISACamp).

\section{Acknowledgements}

To the National Council for Scientific and Technological Development $(\mathrm{CNPq})$ for funding the research and the scholarship productivity $\mathrm{M}$. B. A. Barros and the Ministry of Health and the Department of Health of Campinas for financial support for the survey (Unicamp Partnership/Funcamp). São Paulo Research Foundation (FAPESP) for the PhD scholarship for TF Bastos and the scholarship postdoctoral for PMSB Francisco. 


\section{References}

1. Oliveira MA, Francisco PMSB, Costa KS, Barros MB. Automedicação em idosos residentes em Campinas, São Paulo, Brasil: prevalência e fatores associados. Cad Saude Publica 2012; 28(2):335-345.

2. Costa KS, Barros MBA, Francisco PMSB, Cesar CLG, Goldbaum M, Carandina L. Utilização de medicamentos e fatores associados: um estudo de base populacional no Município de Campinas, São Paulo, Brasil. Cad Saude Publica 2011; 27(4):649-658.

3. Balamurugan E, Ganesh K. Prevalence and pattern of self medication use in coastal regions of South India. BJMP Br J Med Pract 2011; 4(3):a428.

4. Arrais PSP. Medicamentos: consumo e reações adversas: um estudo de base populacional. Fortaleza: Edições UFC; 2009.

5. Coelho Filho JM, Marcopito LF, Castelo A. Perfil de utilização de medicamentos por idosos em área urbana do Nordeste do Brasil. Rev Saude Publica 2004; 38(4):557564.

6. Sans S, Paluzie G, Puig T, Balañá L, Balaguer-Vintró I. Prevalencia del consumo de medicamentos en la población adulta de Cataluña. Gac Sanit 2002; 16(2):121-130.

7. Arrais PSP, Brito LL, Barreto ML, Coelho HLL. Prevalência e fatores determinantes do consumo de medicamentos no Município de Fortaleza, Ceará, Brasil. Cad Saude Publica 2005; 21(6):1737-1746.

8. Bertoldi AD, Barros AJD, Hallal PC, Lima RC. Utilização de medicamentos em adultos: prevalência e determinantes individuais. Rev Saude Publica 2004; 38(2):228-238.

9. Loyola Filho AI, Uchoa E, Guerra HL, Firmo JOA, Lima-Costa MF. Prevalência e fatores associados à automedicação: resultados do Projeto Bambuí. Rev Saude Publica 2002; 36(1):55-62.

10. Bertoldi AD, Barros AJD, Wagner A, Dennis RD, Hallal PC. A descriptive review of the methodologies used in household surveys on medicine utilization. BMC Med Res Methodol 2008; 8:222.

11. Paniz VMV, Fassa AG, Facchini LA, Bertoldi AD, Piccini RX, Tomasi E, Thumé E, Silveira DS, Siqueira FV, Rodrigues MA. Acesso a medicamentos de uso contínuo em adultos e idosos nas regiões Sul e Nordeste do Brasil. Cad Saude Publica 2008; 24(2):267-280.

12. Ribeiro AQ, Rozenfeld S, Klein CH, César CC, Acurcio FA. Inquérito sobre uso de medicamentos por idosos aposentados, Belo Horizonte, MG. Rev Saude Publica 2008; 42(4):724-732.

13. Naves JOS, Castro LLC, Carvalho CMS, Merchan-Hamann E. Automedicação: uma abordagem qualitativa de suas motivações. Cien Saude Colet 2010; 15(Supl. 1):1751-1762.
14. Sá MB, Barros JAC, Sá MPBO. Automedicação em idosos na cidade de Salgueiro-PE. Rev Bras Epidemiol 2007; 10(1):75-85.

15. Obermeyer CM, Price K, Schulein M, Sievert LL, Anderton DL: Medication use and gender in Massachusetts: results of a household survey. Health Care Women Int 2007; 28(7):593-613.

16. Laurenti R, Mello Jorge MHP, Gotlieb SLD. Perfil epidemiológico da morbi-mortalidade masculina. Cien Saude Colet 2005; 10(1):35-46.

17. Barros MBA, Francisco PMSB, Zanchetta LM, Cesar CLG. Tendências das desigualdades sociais e demográficas na prevalência de doenças crônicas no Brasil, PNAD: 2003- 2008. Cien Saude Colet 2011; 16(9):37553768.

18. Verbrugge LM, Wingard DL. Sex differentials in health and mortality. Women \& Health 1987, 12(2):103-145.

19. Figueiredo WS. Assistência à saúde dos homens: um desafio para os serviços de atenção primária. Cien Saude Colet 2005; 10(1):105-109.

20. Pinheiro RS, Viacava F, Travassos C, Brito AS. Gênero, morbidade, acesso e utilização de serviços de saúde no Brasil. Cien Saude Colet 2002; 7(4):687-707.

21. Brasil. Ministry of Health. Portaria no 1944, de 27 de agosto de 2009. Institui no âmbito do Sistema Único de Saúde (SUS), a Política Nacional de Atenção Integral à Saúde do Homem. Diário Oficial da União 2009; 28 ago.

22. Alves MCGP. ISA-Campinas 2008/09: plano de amostragem. [cited 2013 Set 10]: [about 4 p.]. Available from: http://www.fcm.unicamp.br/fcm/sites/default/ files/plano_de_amostragem.pdf

23. World Health Organization (WHO). ATC/ DDD Index 2009 [on line]. [cited 2013 Apr 12]. Available from: http://www.whocc.no/atcdddindexdatabase/

24. DEF - Dicionário de Especialidades Farmacêuticas 2008/2009. 37a ed. São Paulo: Epub; 2009.

25. Dawson DA, Grant BF, Stinson FS, Zhou Y. Effectiveness of the derived alcohol us disorders identification test (AUDIT-C) in screening for alcohol use disorders and risk drinking in the USD general population. $\mathrm{Al}$ cohol Clin Exp Res 2005; 29(5):844-854.

26. Lima CT, Freire ACC, Silva APB, Teixeira RM, Farrel $\mathrm{M}$, Prince M. Concurrent and construct validity of the AUDIT in an urban Brazilian sample. Alcohol Alcohol 2005; 40(6):584-589.

27. Organización Mundial de la Salud (OMS). El estado físico: uso e interpretación de la antropometría. Genebra: OMS; 1995. (Serie de Informes Técnicos, 854).

28. World Health Organization (WHO). A user's guide to the Self Reporting Questionnaire. Geneva: WHO; 1994. 
29. Rocha CH, Oliveira APS, Ferreira C, Faggiani FT, Schroeter G, Souza ACA, DeCarli GA, Morrone FB, Werlang MC. Adesão à prescrição médica em idosos de Porto Alegre, RS. Cien Saude Colet 2008; 10(1):105-109.

30. Barros AJ, Hirakata VN. Alternatives for logistic regression in cross-sectional studies: an empirical comparison of models that directly estimate the prevalence ratio. BMC Med Res Methodol 2003; 3:21.

31. Kish L. Survey sampling. New York: John Wiley and Sons; 1965.

32. Van den Brandt PA, Petri H, Dorant E, Goldbohm RA, Van de Crommert S. Comparison of questionnaire information and pharmacy data on drug use. Pharm Weekbl Sci 1991; 13(2):91-96.

33. Pelicioni AF, César CLG. Uso de medicamentos: In: César CLG, Carandina L, Alves MCGP, Barros MBA, Goldbaum M. Saúde e condição de vida em São Paulo: Inquérito multicêntrico de saúde no Estado de São Paulo - ISA-SP. São Paulo: USP; 2005. p. 199-212.

34. Barros MBA. Saúde e classe social: um estudo sobre morbidade e consumo de medicamentos [thesis]. Ribeirão Preto: Universidade de São Paulo; 1983.

35. Brasil. Ministério da Saúde (MS). Política Nacional de Atenção Integral à Saúde da Mulher/Princípios e Diretrizes. Brasília: MS; 2004. (Série C. Projetos, Programas e Relatórios).

36. Pedro AO, Pinto-Neto AM, Costa-Paiva L, Osis MJ, Hardy E. Procura de serviço médico por mulheres climatéricas brasileiras. Rev Saude Publica 2002; 36(4):484-490.

37. Perrone AMF, Molina MC, Bertonha MEAM, Nativio J, Barros MBA. Use of drugs. In: Barros MBA, César CLG Carandina L, Goldbaum M, organizadores. As dimensões da saúde: inquérito populacional em Campinas, $S P$. São Paulo: Aderaldo \& Rothschild; 2008. p. 218-229.

38. Bardel A, Wallander MA, Svärdsudd K. Reported current use of prescription drugs and some of its determinants among 35 to 65 -year-old women in mid-Sweden: A population-based study. J Clin Epidemiol 2000; 53(6):637-643.

39. Joaquim MR. Automedicação versus indicação farmacêutica [thesis]. Faro: Universidade do Algarve; 2011.

40. Figueiras A, Caamaño F, Gestal-Otero JJ. Sociodemographic factors related to self-medication in Spain. Eur J Epidemiol 2000; 16(1):19-26.

41. Instituto Nacional do Câncer (INCA). Tabagismo um grave problema de saúde pública. [cited 2013 May 5]. Available from: http://wwwl.inca.gov.br/inca/Arquivos/ t_Tabagismo.pdf
42. Gigante DP, Moura EC, Sardinha LMV. Prevalência de excesso de peso e obesidade e fatores associados, Brasil, 2006. Rev Saude Publica 2009; 43(Supl. 2):83-89.

43. Calza S, Decarli A, Ferraroni M. Obesity and prevalence of chronic diseases in the 1999-2000 Italian National Health Survey. BMC Public Health 2008; 8:140.

44. Lima MG, Francisco PMSB, Barros MBA. Sleep duration pattern and chronic diseases in Brazilian adults (ISACAMP, 2008/09). Sleep Med 2012; 13(2):139-144.

45. López-García E, Faubel R, León-Muñoz L, Zuluaga MC, Banegas JR, Rodríguez-Artalejo F. Sleep duration, general and abdominal obesity, and weight change among the older adult population of Spain. Am J Clin Nutr 2008; 87(2):310-316.

46. Gottlieb DJ, Redline S, Nieto FJ, Baldwin CM, Newman AB, Resnick HE, Punjabi NM. Association of usual sleep duration with hypertension: the sleep heart health study. Sleep 2006; 29(8):1009-1014.

47. Lefevre F. A função simbólica dos medicamentos. Rev Saude Publica 1983; 17(6):500-503.

48. Wannmacher L. Tratamento de enxaqueca: escolhas racionais. In: OPAS. Uso racional de medicamentos: temas selecionados - 6. Brasília: OPAS; 2011. p. 55-65.

49. Loyola Filho AI, Uchoa E, Lima-Costa MF. Estudo epidemiológico de base populacional sobre uso de medicamentos entre idosos na Região Metropolitana de Belo Horizonte, Minas Gerais, Brasil. Cad Saude Publica 2006; 22(12):2657-2667.

50. Tesser CD, Barros NF. Medicalização social e medicina alternativa e complementar: pluralização terapêutica do Sistema Único de Saúde. Rev Saude Publica 2008; 42(5):914-920.

Artigo apresentado em 04/10/2013

Aprovado em 11/12/2013

Versão final apresentada em 18/12/2013 
